\title{
Students Can Control Their Emotions
}

\author{
Saba Harati (Corresponding Author) \\ School of Educational studies, Universiti Sains Malaysia (USM) \\ PO box 11800, Penang, Malaysia \\ E-mail: saba.hr3147@yahoo.com \\ Nasrin Arian Parsa \\ School of Educational studies, Universiti Sains Malaysia (USM) \\ PO box 11800, Penang, Malaysia \\ E-mail: nasiarian@yahoo.com
}

Doi:10.7575/aiac.alls.v.5n.4p.202

Received: 18/06/2014

URL: http://dx.doi.org/10.7575/aiac.alls.v.5n.4p.202

Accepted: 07/08/2014

\begin{abstract}
As emotional intelligence contributes extensively in people's lives, it can also find some significance in language teaching. From this perspective, it is inevitable for teachers to know how to improve students' emotional intelligence. This paper made an effort to provide procedures to develop emotional intelligence. Although success has various definitions from one theory to other, in this presented theory-emotional intelligence - success will be achieved when students can control their emotions. This paper attempts to mark a common perception of behaviors that the teachers can employ to enhance students 'control over their emotions.
\end{abstract}

Keywords: Empathy, Emotional intelligence, Humanism, Intelligence, Praxis

\section{Introduction}

Emotional intelligence is not a temporary fashionable educational trend as it can be traced back to long years ago. It seems new only because it was shuffled aside, and has been "sent into hibernation by the 20th century's fixation on scientific data and rationalism at any cost" (Stain \& Book, 2006). However, in the recent years emotional intelligence increasingly has been recognized crucial to effective teaching. One of the reason for such popularity "appears to be the high regard for the concept of intelligence, as it is a desirable quality that is associated with power, expertise, and prestige" (Pellitteri, 2006, p. 29).

"Juxtaposing intelligence and emotion appears to be a potential capacity to use emotional intelligence to facilitate thought" (Goleman, 1995, 1998). The term intelligence, has been defined diversely in different sources, however, Sternberg (1990) suggests a list of attributes that can identify some of its specific attributes as follow: knowledge, ability to learn, speed of mental processing, ability to deal with novelty, academic abilities, 'g' factor, which is valued by culture, executive processes, not one construct, and metacognition' (Sternberg, 1990). Moreover, Sternberg elaborating on the distinction between intelligence and intelligent behavior defines intelligence as a set of stable mental processes used to produce intelligent behavior. Fer (2004), in the same line, affirms that the term emotional intelligence is a broad comprehensive term referring to inter- and intra-personal skills, being aware of emotions, and using emotional and social abilities. From this perspective, it is time to step aside the theory and delve into practice by suggesting the ways that emotional intelligence can be utilized in language teaching. In this sense, this paper makes an endeavor to provide a quick review of underlying concepts of emotional intelligence on one hand, and deals with the practical implication of emotional intelligence in language teaching on the other hand.

\section{Review of Related Literature}

\subsection{WHAT IS EMOTIONAL INTELLIGENCE?}

Moritboys (2005) maintains employing emotional intelligence in teaching is highly effective to change in learners' perception. When the teachers invest enough energy to plan the lessons and to get prepared to meet students' demands, the students will respond to the teachers' actions differently Empathy is the capacity to share and understand another person's state of mind (Ioannidou \& Konstantikai, 2008) and establishing connections and empathy from the teachers' side is a necessity to communicate with the students, thus a descent degree of empathy is needed. Empathy, in contrast with sympathy, involves attachment. In fact, no methods can exert positive effect on the process of learning if there is no desire on the part of teachers to create a climate that students become free to learn (Rogers, 1983). Thus, setting up a non-defensive environment is indispensible to facilitate the process of learning and teaching.

Furthermore, to be emotionally intelligent, the teacher should reach a well-developed self-awareness. According to Jensen (1998) "all learning is state dependent" (cited in Moritboys, 2005, p. 29). Moritboys concurs that the state you are in is characterized by the collection of emotions you are feeling. Human beings usually live in the way they think, 
thus, in the class there is a great deal of potentialities that induce feelings that do not create a learning state. Therefore, it is the responsibility of teachers to shape and direct and channel students' feeling in correct paths.

An ideal learning state has been described by Csikszentmihalyi (2002) as a flow which refers to the state when one gets completely absorbed by a task. Henceforth, in this context, anxiety will be stuck to the margin, and undoubtedly letting students express their feelings from their vantage points is the first steps to recognize their emotional dimensions of their own learning.

Specifically, teachers' burnout (i.e., emotional exhaustion, depersonalization, and reduced personal accomplishment) and stress might reduce the quality of teaching, and might also lead to job dissatisfaction, work alienation, physical and emotional problems, and ultimately quitting the job (Chan, 2006). Thus, increasing teachers' emotional intelligence entails encouraging individuality as well as students' collective identities.

\subsection{EMOTIONAL INTELLIGENCE AND HUMANISM}

Emotions have been the subject of philosophical inquiry for centuries and focusing on students' emotion has a deep humanistic pedagogy. The philosophy behind humanistic perspective can be investigated from different streams of thoughts. In this regard, Gadd (1998) makes a distinction between romantic, pragmatic, and rhetorical views towards humanism. Romantic humanists place emphasis on students' emotions and claim by invoking their inner selves, successful learning will be encouraged. Pragmatic humanism, according to Gadd (1998), in contrast, he argues that understanding students' motivations, attitudes, reactions, and cognitive strengths and weaknesses is indispensible to respond more effectively to their needs.

In his article, Gadd (1998) asserts that teachers are only concerned about the development of learners' feelings and emotions. What is plausible to assert is that to Gadd, we are more concerned with the affective side of human beings rather than the cognitive. In effect, considering human beings it is the combination of the affective and the cognitive features that stimulate the personal development as a whole character (Arnold, 1998). However, it is hard to say that a person with high cognitive ability might benefit the same level of affective ability. Nevertheless, in Goleman's (1995) emotional intelligence definition has been pointed out that there are individuals with a low IQ that often do better in life than those with a high IQ. According to Goleman, this ability has been rooted in the emotional intelligence.

To achieve appropriate emotional control and emotional awareness, young children require many opportunities to observe in adult models such as, a secure base of relationships with others, and loving guidance as they try out their emerging skills in many contexts (Hyson, 2004). In the line with education, Mayer and Salovey (1990), in an attempt to discover different aspects of emotional intelligence, suggest the following guide lines and state that a teacher should : (a) let students express their feelings instead of stopping them they misbehave; (b) take responsibility for their feelings instead of imposing them your judgments ; (c) be much more aware of feelings of the students; (d) try to understand the reasons behind students' behavior before forming an opinion about them; (e) find ways for voluntary cooperation instead of making demands and obligation, and (f) help students to express themselves openly to solve any problems they may have.

Such a context offered by Mayer and Salovey does not occur unplanned and to set up the situation a descent degree of empathy is required. As Brown (2000) claims, to communicate effectively, we need to be able to understand the other persons' affective and cognitive states. Communication fails when false assumptions are made about the other person's state. To him, empathy is defined as the projection of one's own personality into the personality of another. Empathy implies detachment and is not synonymous with sympathy which connotes attachment. In fact, as Sucaromana (2012) offers emotional intelligence and achievement are integrated with each other and have strong connections. No one can deny by improving students' interpersonal skills develop, learning is automatically enhanced (Elliot, 2003, cited in Sucaromana, 2012). Furthermore, increasing one's emotional intelligence has explicit connections with academic achievements that have a significant role on the learning context, and on students' cognitive achievement, thereby on the effort to direct the students to correct path. However, what is necessary to be considered is how emotional intelligence can be developed by teachers.

Having emotional intelligence is a necessity on the part of teachers to both provide a non-defensive environment and help students to increase their emotional intelligence. Teachers are always in an attempt to see success in their students. The achievement of success is variously defined by different theories. In this theory-i.e., emotional intelligencesuccess will be achieved when students can control their emotions. Long has been reported on the denotative and connotative meaning of emotional intelligence, but now it is time to delve into the strategies and techniques those students can employ in order to control their emotions.

No one denies that a teacher who does not meet students' emotional needs will not gain any success among his or her students. The inability of teachers to align their actions with the theory shows up more obviously when newcomer teachers fail to cope with troublesome students. There is no doubt that every classroom has students that are considered challenging for inexperienced teachers. At some points, the generosity and good will of the teacher is strained, causing those teachers to realize that they are in the center of a power struggle and that it is affecting their teaching and their life outside the classroom. Boice (1996) has coined the term "classroom terrorists" for these particularly troublesome, unruly students (cited in Carlson, 1997). To him, the presence of one or perhaps two classroom terrorists who show unpredictable and highly emotional outbursts, make the entire class emotionally uncomfortable and uncontrollable (Carlson, 1997). In such classes, even with one classroom terrorist, it is inevitable to the teachers to revise their disciplinary perspectives. 
It is evident that while a reflective teacher in an attempt can evoke student's emotional intelligence, sticking to the lesson plan will not gratify the students' unmet emotional needs therefore, the students are usually seen as terrorists or disruptions to the class and to the attainment of the lesson plan. It has been regarded important to notice that in order to develop students' emotional intelligence; a particular kind of relationship is required between teacher and learners, and among learners. The relationship is one where learners and teacher are bound and work together so that they jointly construct meaning and knowledge with the material. To Giddens (1994, cited in Gergen, 2003) through dialogue, personal relationship develops and builds up the trust. In fact, through dialogues some sorts of connections can be established between the teacher and students. In this sense, the interactions and dialogues provide a potential context that students can liberate their emotions, feeling and potentials. To Prabhu (1987), the rapport represents a form of empathetic understanding of each other's behavior and is probably more productive of learning than any teaching procedure by itself can be. In fact, as Prabhu asserts, without dialogue, the teacher is forced to apply his/her authorization in teaching so that the classroom can easily cease to be a source of interpretable experience.

Last but not the least, for students to control their behaviors, learners need to be engaged both cognitively and affectively in the process of language acquisition. Without affective and cognitive involvement, there is little possibility of deep processing (Craik \& Lockhart, 1972) and therefore little chance of language acquisition. One way to see the engaging effect is to design activities which involve learners' personal experiences, attitudes, and views so that students can be humanistically engaged in praxis (Freire, 1970). Praxis involves a give-and-take relationship between theory and practice - between theorizing practice and practicing theory. In Freire's philosophy, praxis and dialogue are tightly connected: genuine dialogue represents a form of humanizing praxis. If praxis is to be humanizing, dialogical communication must involve a love of the world and of other human beings.

\section{Conclusion}

Emotional intelligence is a revolutionary concept that has promoted standards of education over the last twenty years. In this field of research emotions have not been treated as a controversial concept for rationality, thus the hybrid term 'emotional intelligence' is seemingly ambiguous. Nevertheless, philosophically speaking, emotional intelligence refers to the competence to identify and express emotions, understand emotions, assimilate emotions in thought, and regulate emotions in the self and in others (Lazarus, 1991). Thus, I haven't gone too far if I claim that abstract rationality embeds intelligence, albeit with stance of emotionality as an epitome of intelligence that should not be disregarded. In this line, the concept of emotional intelligence, though brings us back into the discussion of instrumental behaviorism, should be lauded. Henceforth, emotional intelligence, not only has been considered as a panacea for the problems of language teaching, but also is a construct which deserves closer scrutiny and development.

No one denies that teaching is a political act and that a language teacher is an agent for change (Brown, 1994). Brown warns teachers not to push a particular philosophy on our students, but let them negotiate meaning harmoniously. However, teachers must not limit themselves to the development of students' inner selves, but help students to develop the intellectual skills and strategies so that they can cope with their demands in a great variety of situations, and therefore, control their emotions.

\section{References}

Arnold, J. (1998). Towards more humanistic English teaching.ELT Journal, 53 (3), 235-242.

Brown, H. D. (1994). Teaching by principles.Englewood Cliffs, N.J.: Prentice Hall Regents.

Brown, H.D. (2000). Principles of language learning and teaching. Longman: Person Education Company.

Carlson, V. M. (1997). When new teachers meet the classroom terrorist. Retrieved in 2011 from http://teaching. berkeley.edu/classroomproblem.html

Chan, D. W. (2006). Emotional intelligence and components of burnout among Chinese secondary school teachers in Hong Kong. Teaching and Teacher Education.doi:10.1016/j.tate.2006.04.005.

Csikszentmihalyi, M. (2002). Flow.London: Rider

Fer, A. (2004). Qualitative evaluation of emotional intelligence in-service program for secondary school teachers. The Qualitative Report, 9 (4), 562-588.

Freire, P. (1970). Pedagogy of the oppressed. New York: Continuum.

Gadd, N. (1998). Towards less humanistic English teaching. ELT Journal, 52 (3), 223-233.

Gergen, K. J. (2003). Action research and orders of democracy. Action Research, 1(1), 3956.doi:10.1177/14767503030011004

Goleman, D. (1995). Emotional Intelligence: Why it can Matter more than IQ. London: Bloomsbury.

Goleman, D. (1998). Working with emotional intelligence. London: Bloomsbury Publishing.

Hyson, M. (2004). The emotional development of young children. London: Teachers College Press.

Ioannidou, F., \& Konstantikai, V. (2008). Empathy and emotional intelligence: What is it really about? International Journal of Caring Sciences, 1 (3), 118-123.

Lazarus, R. (1991). Emotion and adaptation.New York:Oxford University Press 
Mayer, J. D., \& Salovey, P. (1990). Emotional intelligence. Imagination, Cognition, and Personality, 9, $185-211$.

Pellitteri, J. (2006). Emotional intelligence: Theory, measurement, and counseling implications. In J. Pellitteri, R. Stern, C. Shelton \& B. Muller-Ackerman (Eds.), Emotionally intelligent school counseling (pp. 29-48). London: Lawrence Erlbaum Associates, Publishers.

Prabhu, N. S. ( 1987 ). Second language pedagogy. Oxford: Oxford University Press.

Rogers, C. (1983). Freedom to learn for the 80's. Columbus, OH: Merrill.

Stain, S. J., \& Book, H. E. (2006). The EQ edge: Emotional intelligence and your success. Toronto: Jossey-Bass

Sternberg, R. J. (1990). Metaphors of mind: Conceptions of the nature of intelligence. New York: Cambridge University Press.

Sucaromana, U. (2012). Contribution to language teaching and learning: A review of emotional intelligence. English Language Teaching, 5 (9), 54-58. doi:10.5539/elt.v5n9p5. 